\title{
APPLICATION OF LANDSAT-DERIVED NDVI IN MONITORING AND ASSESSMENT OF VEGETATION COVER CHANGES IN CENTRAL SERBIA
}

\author{
Miško M. MILANOVIĆ ${ }^{1}$, Tanja MICIĆ ${ }^{2 *}$, Tin LUKIĆ ${ }^{1,2}$, Snežana S. \\ NENADOVIĆ ${ }^{3}$, Biljana BASARIN ${ }^{2}$, Dejan J. FILIPOVIĆ ${ }^{1}$, Milisav TOMIĆ ${ }^{4}$, \\ Ivan SAMARDŽIĆ ${ }^{1}$, Zoran SRDIĆ ${ }^{5}$, Gojko NIKOLIĆ ${ }^{6}$, Miloš M. NINKOVIĆ ${ }^{1}$, \\ Dušan SAKULSKI ${ }^{7}$ \& Branko RISTANOVIĆ ${ }^{2}$ \\ ${ }^{1}$ University of Belgrade, Faculty of Geography, Studentski trg 3/3, 11000 Belgrade, Serbia; \\ ${ }^{2}$ University of Novi Sad, Faculty of Sciences, Department of Geography, Tourism and Hotel Management, Trg Dositeja \\ Obradovića 3, 21000 Novi Sad, Serbia, corresponding author: tanja.micic91@gmail.com \\ ${ }^{3}$ Laboratory for Material Science, Institute of Nuclear Sciences " Vinča", POBox 522, University of Belgrade, 11000 \\ Belgrade, Serbia, \\ ${ }^{4}$ Service for the Protection and Improvement of the Environment, Branch RB Kolubara, Faculty of Forestry, \\ University of Belgrade, Lazarevac 11550, Serbia \\ ${ }^{5}$ Military Geographical Institute, Mije Kovačevića 5, 11000 Belgrade, Serbia. \\ ${ }^{6}$ University of Montenegro, Faculty of Philosphy, Institute for Geography, Danila Bojovića 3, 81400 Nikšić, \\ Montenegro. \\ ${ }^{7}$ University of Novi Sad, BioSense Institute, Zorana Đinđića 1, 21000 Novi Sad, Serbia.
}

\begin{abstract}
This paper evaluates the application of the Normalised Difference Vegetation Index (NDVI) in the monitoring and assessment of temporal vegetation cover changes (from 2006 to 2014) in three municipalities of Central Serbia: Topola, Jagodina and Kuršumlija. Additionally, special focus is placed on the analysis of the forest areas and the possible use of NDVI in the forest management sector. Results of the NDVI applied through Idrisi software identify all vegetation cover types and their typical values for presented case studies and observed periods. Obtained results for Serbian case studies indicate two major observations outlined for the investigated period. It was noticed that vegetation cover is experiencing a certain decrease, and that certain discrepancies exists between the NDVI and official forest area statistics for certain municipalities. The study outlines the positive outcomes of the applied remote sensing techniques, especially for southern Serbian municipalities where illegal logging activities are pronounced. Hence, this method proved very promising for countries performing national forest inventories, such as Serbia, providing local forest managers with several essential up-to-date information about vegetation cover changes on an annual basis.
\end{abstract}

Key words: NDVI, vegetation cover, temporal changes, forest management, Central Serbia

\section{INTRODUCTION}

Due to the expansion and development of modern technologies, Serbia, as a country in a transitional process with a growing economy (considerably depended on agriculture), needs to develop and implement adequate measures and methodologies to monitor and assess the temporal changes in vegetation cover at macro level, and especially at micro level. This approach can greatly contribute to the increase in productivity and competitiveness of domestic agricultural production, as well as other economic sectors (e.g. forestry).

During the last more then 30 years, remote sensing has been used for the continuous monitoring of the Earth's surface, providing the opportunity to analyze changes in vegetation cover (Ladányi et al., 2011). As pointed out by Jovanović et al. (2015), remote sensing is the science, and to some extent the applied geo-science discipline for acquiring 
information about the Earth's surface without actually being in direct interaction with it. Jovanović \& Milanović (2015) stated that remote sensing could be defined as the detection, recognition or evaluation of objects by means of distant sensing or recording devices. Remote sensing systems provide a continual and consistent view of the Earth's surface with the ability of monitoring the Earth's system and human influence, especially over wide, open areas (Jovanović et al., 2015).

Remote sensing has a wide range of applications in agriculture and forestry: from monitoring seasonal changes to observing the development level of crops, monitoring plant diseases, analysis of the state of vegetation, floods, forest fires, classification of crops, air and water pollution (Milanović et al., 2016; 2017).

The main characteristics of successful remote sensing applications in the forestry sector lies in the necessity for up-to-date information over an area too large or too difficult to survey on the ground (Franklin, 2001). Illegal and corruptive activities are pointed out as a major underlying cause of forest decline (Brack, 2003; Edmunds \& Wollenberg, 2004; Blaster et al., 2005; Markus-Johansson et al., 2010), and the main cause is stated as the lack of control over illegal operations by the government and private landowners. On the other hand, there has been a large shift regarding forest management authorities globally, going from central government level to municipal level (USA, Canada, China, India, Indonesia, etc.) (Edmunds \& Wollenberg, 2004).

The Balkan Peninsula (southeast Europe), as the great hotspot of European biodiversity, is providing outstanding levels of endemism and refugial habitats (Griffiths, et al., 2004). Outstanding vegetation biodiversity in the Balkans is a consequence of a specific geographical position, complex geomorphology, and Pleistocene climatic fluctuations (Willis, 1994; Tzedakis, et al., 2002; Basarin, et al., 2011; Marković, et al., 2014; Obreht et al., 2014). However, natural vegetation was dramatically influenced by human activities since the Palaeolithic period onward. Hence, vegetation conservation and adequate monitoring are great ecological challenges in this part of the world.

NDVI has been used in the monitoring of the state of vegetation in Serbia, with the accent on forest cover, on several occasions. For instance, Rašković (2015) analysed the environmental status of the two protected forest areas in the Belgrade area Košutnjak forest and Zvezdarska forest. For a clear presentation of the devastating anthropogenic impact on protected forest ecosystems, an NDVI analysis of the appropriate satellite image segments were performed in order to detect the differences in the state of vegetation covers in 1986 and 2010 . Calculation of the quantitative parameters provided insight into the intensity, but also the consequences of progressive degradation processes that have shaped these areas over the past few decades due to the expansion of facilities and infrastructure in the protected zones. Jovanović \& Milanović (2015) showed that the determination of a spectral index of vegetation is of great help where local forest management is concerned. The authors pointed out that NDVI can have great applicative value in assessing the forest degradation. Jovanović et al., (2015) applied various methods in order to detect land cover changes at Zlatibor Mountain (Western Serbia). The results of the case study provided information which led to the conclusion that the surface underneath the forest is reduced to about 4\% (or about 1000 ha), while the urban area has doubled (grown about 600 ha) during the examined period from 1985 to 2013. Jovanović et al., (2018) performed an evaluation on the use of the NDVI and CORINE Land Cover (CLC) databases for the improvement of forest management in the municipalities of Kuršumlija and Topola (Southern Serbia). The authors pointed out that the forest areas obtained with CLC were up to 11.5\% larger than the official forest area estimates, whereas NDVI gave results that were more precise. Hence, NDVI proved to be more effective to local forest managers for essential annual information about the forest inventory in order to prevent illegal logging. This approach has shown that the utilisation of NDVI could be very promising for Serbia and the countries that rarely carry out national forest reports.

The main purpose of this research is to analyse temporal changes in vegetation cover of three Serbian municipalities with different topographical features by applying the NDVI method. This index has proved to be a very efficient tool for the classification and estimation of different land cover types in vast, remote areas (e.g. Meng et al., 2009). It evaluates the suitability of local forest management as well as the statistical recording of forestry methodology in Serbia. In addition, the results of this study can easily be applied to other Balkan countries with similar situations concerning local forest management.

\section{MATERIAL AND METHODS}

\subsection{Study area}

The presented study encompasses three municipalities in Central Serbia with different topographical features: plains (Jagodina Municipality), plains and low hills (Topola 
Municipality), and high hills (Kuršumlija Municipality) (Fig. 1).

The territory of the Topola Municipality is located in Central Serbia, covering approximately $357 \mathrm{~km}^{2}$, with $51 \mathrm{~km}^{2}$ (14\%) of its total area under forest vegetation. The municipality consists of the river basin and the potamon zone of the Jasenica and Kubršnica rivers, as well as the Rudnik and Venčac Mountains, stretching along the western and southwestern parts of the municipality. The average elevation of the municipality is $350 \mathrm{~m}$, with the lowest point at $128 \mathrm{~m}$ and the highest at $1048 \mathrm{~m}$ (Jovanović \& Milanović, 2015). The municipality of Jagodina $\left(470 \mathrm{~km}^{2}\right)$ is situated in the basin of the Belica River in the Pomoravlje region of Central Serbia. With an average elevation of $116 \mathrm{~m}$, Jagodina is the municipality with the lowest topography (Milanović et al., 2016). Kuršumlija Municipality is located in the south of Central Serbia at the administrative border of Kosovo and Metohija and occupies $952 \mathrm{~km}^{2}$. The municipality is situated near Toplica River on the southeast of Kopaonik Mountain and northwest of Radan Mountain. The average elevation of the municipality varies from $300 \mathrm{~m}$ to 1703 m (Jovanović et al., 2018).

\subsection{Satellite data, pre-processing, and calculation of NDVI}

The results for Topola, Jagodina and Kuršumlija municipalities obtained by NDVI for the summer season of 2006 and 2014 were validated with official forest area estimates for the same period (Fig. 2). A reliable long-time comparative analysis between NDVI results and official forest inventories couldn't be conducted, since the national forest inventory in Serbia has been performed during 1961, 1979, and 2003-2006. Since 2007, official estimates of forest areas in Serbia have been done and published on an annual basis.

NDVI data (Table 1) for all three municipalities are based on LANDSAT 5 Thematic Mapper (TM) satellite images for 2006 and LANDSAT 8 for 2014 (July 18, 2006 and August 22, 2014) (www.usgs.gov).

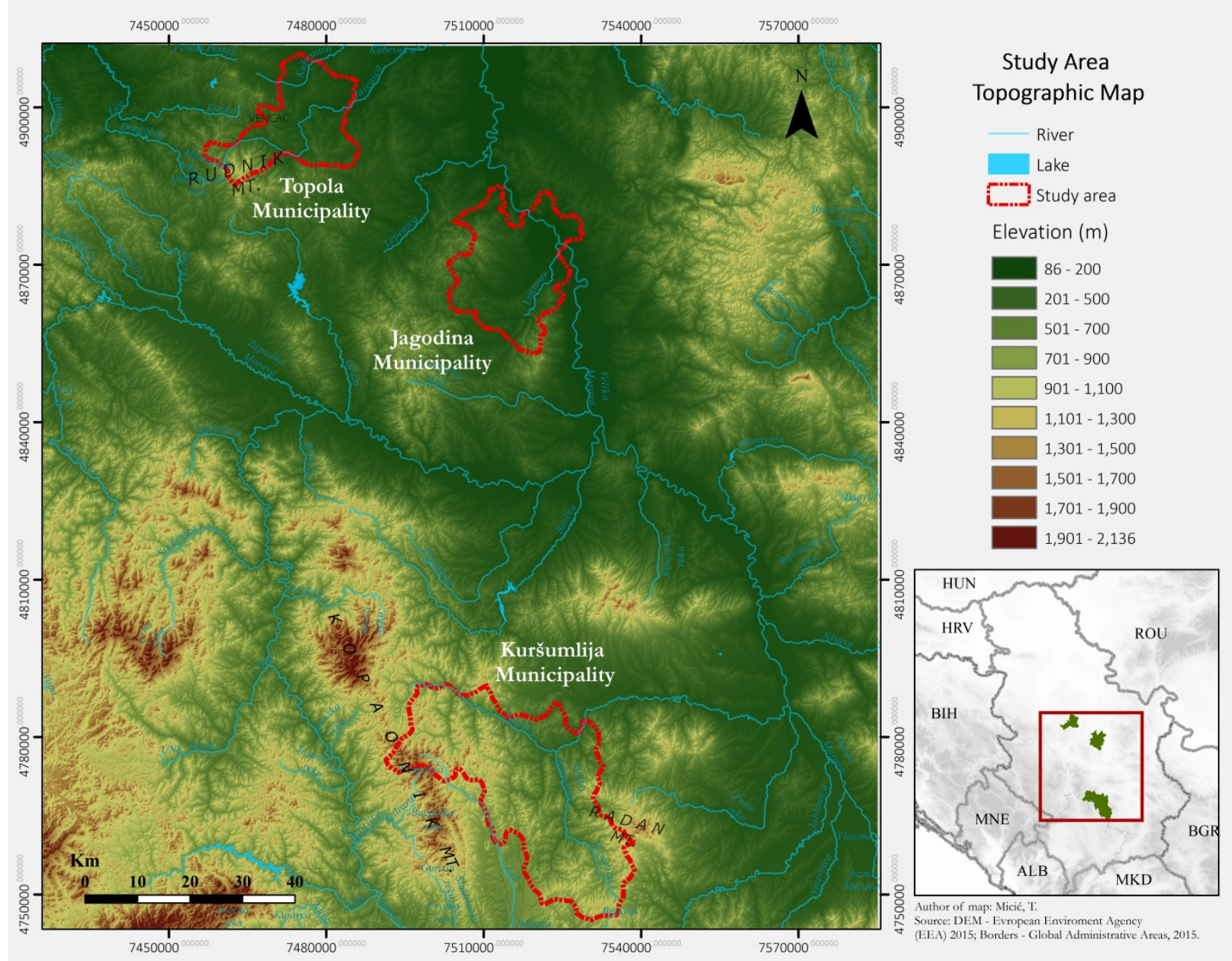

Figure 1. Location of the investigated municipalities in Central Serbia 


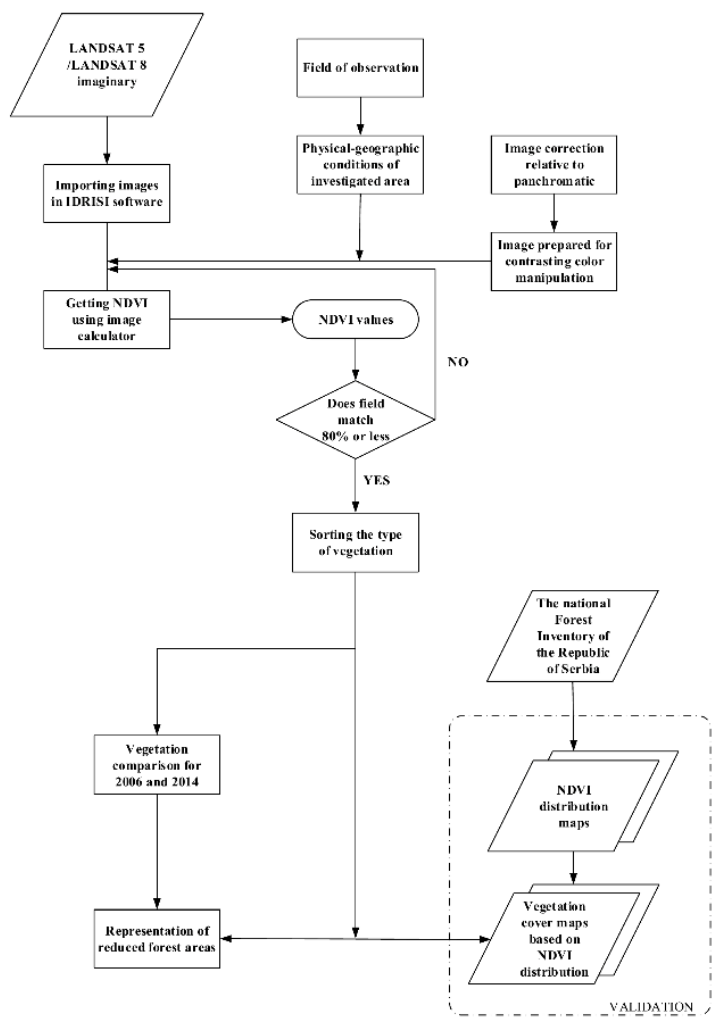

Figure 2. Working steps

The images were created during July and August, with minimum cloud cover (10-20\%) as suggested by Chavez (1996). In order to remove atmospheric effects from the final NDVI results, Idrisi software was applied for data pre-processing. As of 2010 satellite images available on the United States Geological Survey (USGS) website have already undergone atmospheric correction. In addition, there was no need to apply atmospheric correction on older images because they were made during clear weather conditions.

LANDSAT satellite imagery (30 m resolution) and pan-sharpening images (15 m resolution) were used for the calculation of the NDVI in order to obtain the most precise results. NDVI is one of the most widely used vegetation indices. One of the main features of this index is the fact that its main focus is on the vegetation cover and the status of the cover itself (Jensen, 2007; Jovanović et al., 2018).

As pointed out by Ladányi et al. (2011), vegetation indices have been widely used to estimate biomass quantity and to evaluate vegetation conditions. The NDVI is a commonly used tool for evaluating the dynamics of vegetation. The index shows the alteration of green biomass quantity, chlorophyll content, and water-stress of leaf surface (Ladányi et al., 2011). NDVI, like all the vegetation indices, relates the spectral absorption of the chlorophyll in red $(R)$ with a reflection phenomenon in the near infrared spectrum (NIR), influenced by the leaf-structure type (Wang \& Tenhunen, 2004). The index is based on the fact that chlorophyll pigments of plant leaves absorb the radiation in the 0.4 to 0.7 $\mu \mathrm{m}$ range of visible light (photosynthesis), but the structure of plant leaves reflects the radiation in the near-infrared range $(0.7$ to $1.1 \mu \mathrm{m})$. The values of NDVI vary between -1 (clear/deep water-surfaces, bare lands) and +1 (dense forests) (Ladányi et al., 2011). In order to obtain forest-area data with $15 \mathrm{~m}$ precision, we used NDVI and applied the necessary corrections of visible red band in the constellation with an infrared spectrum of LANDAT 8 satellite images, using the following procedure:

$$
R_{n}=\frac{R}{R+G+B} \times P A N
$$

Table 1. Landsat 5 (2006) and Landsat 8 (2014) images used in the analysis

\begin{tabular}{|c|c|c|c|c|}
\hline \multirow{2}{*}{$\begin{array}{c}\text { Band } \\
\text { No. }\end{array}$} & \multicolumn{2}{|c|}{ Landsat 5 } & \multicolumn{2}{c|}{ Landsat 8 } \\
\cline { 2 - 5 } & $\begin{array}{c}\text { Bandwidth } \\
(\mu \mathrm{m})\end{array}$ & $\begin{array}{c}\text { Resolut. } \\
(\mathrm{m})\end{array}$ & $\begin{array}{c}\text { Bandwidth } \\
(\mu \mathrm{m})\end{array}$ & $\begin{array}{c}\text { Resolut. } \\
(\mathrm{m})\end{array}$ \\
\hline 1 & $0.45-0.52$ & 30 & $0.43-0.45$ & 30 \\
\hline 2 & $0.52-0.60$ & 30 & $0.45-0.51$ & 30 \\
\hline 3 & $0.63-0.69$ & 30 & $0.53-0.59$ & 30 \\
\hline 4 & $0.76-0.90$ & 30 & $0.64-0.67$ & 30 \\
\hline 5 & $1.55-1.75$ & 30 & $0.85-0.88$ & 30 \\
\hline 6 & $10.40-$ & 120 & $1.57-1.65$ & 30 \\
\hline 7 & 12.50 & & & 30 \\
\hline 8 & $2.08-2.35$ & 30 & $2.11-2.29$ & 15 \\
\hline 9 & $/$ & $/$ & $0.50-0.68$ & 30 \\
\hline 10 & $/$ & $/$ & $1.36-1.38$ & 100 \\
\hline 11 & $/$ & $/$ & $10.6-11.19$ & 100 \\
\hline
\end{tabular}




$$
\begin{aligned}
& G_{n}=\frac{G}{R+G+B} \times P A N \\
& B_{n}=\frac{B}{R+G+B} \times P A N
\end{aligned}
$$

where:

$R$ - red channel;

$R_{n}$ - new/adjusted red channel:

$G$ - green channel;

$G_{n}$ - new/adjusted green channel;

$B$ - blue channel;

$B_{n}$ - new/adjusted green channel;

and the given equation:

$$
N D V I=\frac{N I R-R}{N I R+R}
$$

where NIR is near the infrared channel, and $R$ stands for the red channel from the visible part of the spectrum.

The downloaded images have a $30 \mathrm{~m}$ resolution, and are panchromatic only at a $15 \mathrm{~m}$ resolution. For this reason, other channels have been adjusted according to the panchromatic channel, in order to enhance image resolution following the approach of Jovanović \& Milanović (2015) and Jovanović et al., (2018).

Image processing and NDVI validation were performed by using the image calculator option of the Idrisi software package.

Basic tasks (accurate determination of boundaries between areas of different vegetation classes) included an analysis and photointerpretation of given elements, occurrences, and processes detected on images by Idrisi software that is used for the processing of remotely sensed images through the application of NDVI (Johnson \& Trout, 2012).

Water bodies (lakes and rivers) have rather low reflectance in both spectral bands (at least away from shores), thus resulting in very low positive or even slightly negative NDVI values. On the other hand, vegetation areas are presented with values between 0 and 1 (e.g.; Bakx, 1995; Finelli et al., 1996; Schmitt \& Ruppert 1996; Ladányi et al., 2011; Jovanović \& Milanović, 2015; Jovanović et al., 2018). NDVI values for corresponding vegetation types are the result of contrast manipulation depending on the cover type and vegetation density (Fig. 2). The cover type, depending on the amount of sunlight passing through the branches, can be distinguished in the image processing as dense ( $<25 \%$ sunlight passed), medium (25-50\%) and sparse cover types (>50\% sunlight passed) (e.g. Grădinaru et al., 2017; Jovanović et al., 2018). Thus, the intensity, hue, and saturation of the RGB multispectral colour was transformed. Coefficients of these parameters are obtained using the following procedure:

$$
\begin{aligned}
l & =\max (R, G, B) \\
L & =\frac{R+G+B}{3} \\
L^{\prime} & =\frac{\max (R, G, B)+\min (R, G, B)}{2}(7)
\end{aligned}
$$

where:

l- the maximum colour coefficient for all three channels (for each pixel);

$L$ - the arithmetic mean of shades for all three channels (for each pixel);

$L^{\prime}$ - colour saturation coefficient (used for contrast manipulation).

On the images of the analyzed area 20 points asymmetrically distributed over the municipality were selected by using random sampling. Results of satellite images processing, i.e. NDVI for the 20 selected points were checked in the field. If the results matched in $80 \%$ of the cases, then the use of NDVI was justified, as shown in Fig. 2. If the accuracy was below $80 \%$, the procedure (according to the algorithm shown in Fig. 2) would be repeated, i.e. NDVI validation would be redone. Therefore, the validation process was obtained with $20 \%$ mismatch tolerance regarding the official forest inventories.

\section{RESULTS AND DISCUSSION}

As mentioned in the previous section, the raster NDVI for the Topola, Jagodina, and Kuršumlija municipalities were calculated from the LANDSAT satellite images for 2006 and 2014. The LANDSAT satellite images were obtained through software processing and a combination of the individual spectral channels. NDVI values are within range -1 to 1 , where negative values represent lack of vegetation or diseased vegetation, and positive values are showing healthy, dense vegetation.

The smallest temporal change in NDVI values has been registered for the Topola Municipality (Fig. 3a-b).

High negative values of NDVI are observed for the northern part of the municipality from 2006 onward. The slight decrease of green, healthy vegetation areas can be observed in the southwestern parts of the municipality during the investigated period.

The greatest changes have been observed in the Jagodina Municipality (Fig. 3c-d) over time. Fig. 3c 
indicate the presence of only a few green areas in the central parts of the municipality, while the northwestern and eastern border parts are recognised as potentially 'damaged'. Fig. 3d suggests a better situation for most damaged parts of the municipality, with higher positive values recorded in the central parts.
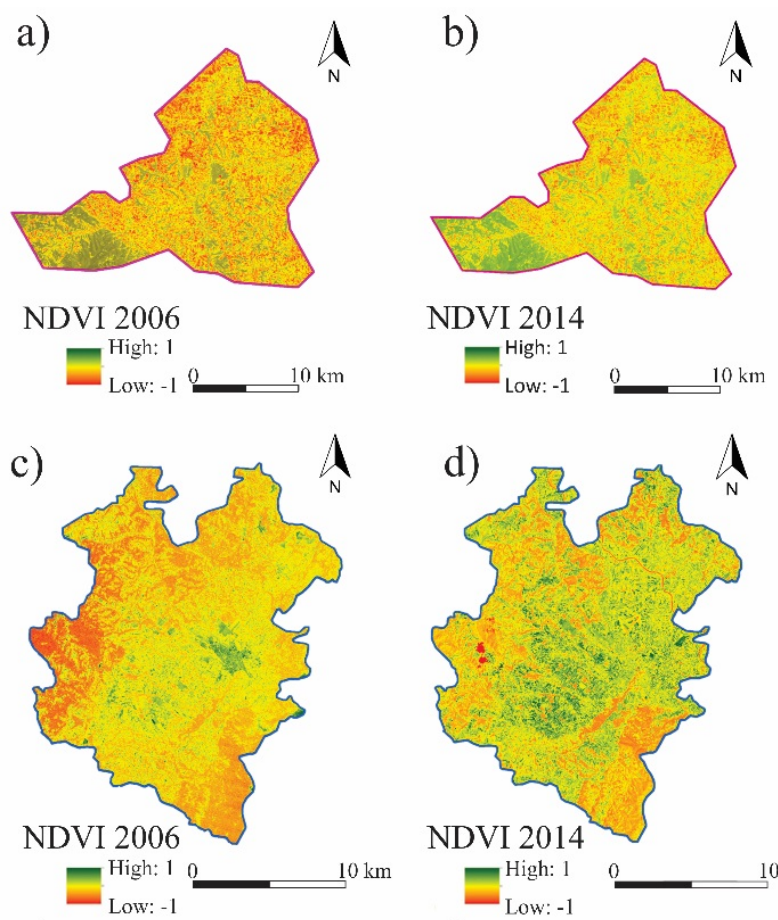

e)

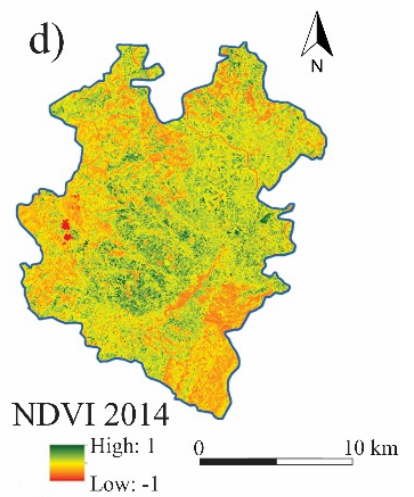

f)
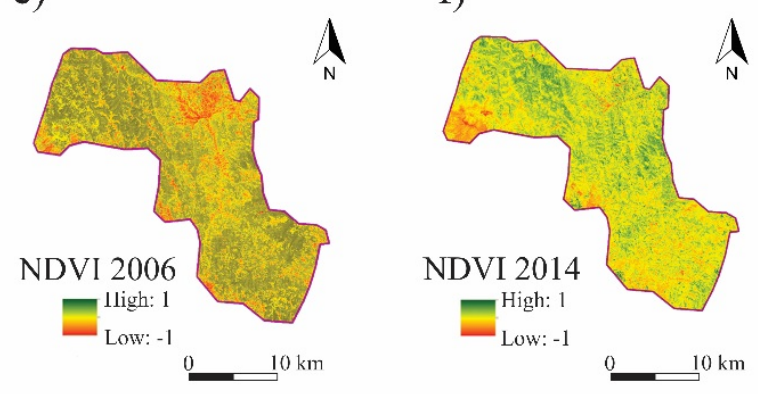

Figure 3. NDVI values for Topola (a, b), Jagodina (c, d), and Kuršumlija (e, f) municipalities

For Kuršumlija Municipality (Fig. 3e-f), two areas of interest have been observed. First, the increase of healthy vegetation over the observed period in the basin of the Toplica River in the northeastern part of the municipality. The second area of interest, located in the north-western part of the municipality, has detected increasing negative values from 2006 to 2014. Furthermore, it can be pointed out that the dark green areas in the central and southern part of the municipality have been decreasing over the time, indicating the presence of a deforestation process.

The vegetation types are given as the result of contrast manipulation for corresponding NDVI values regarding the cover type and vegetation density (Table 2). Contrast manipulation represents a process of sharpening blurry edges of contours of a specific class in order to clearly distinguish between two adjacent features (Jovanović et al., 2018).

Table 2. NDVI values for vegetation land cover

\begin{tabular}{|l|r|}
\hline Vegetation land cover & NDVI values \\
\hline Meadow & $0-0.122$ \\
\hline Sparse vegetation & $0.123-0.174$ \\
\hline Shrubs & $0.175-0.230$ \\
\hline Vineyards & $0.231-0.262$ \\
\hline Orchards & $0.263-0.291$ \\
\hline Broad-leaved forest & $0.292-0.438$ \\
\hline Mixed forest & $0.439-0.525$ \\
\hline Coniferous forest & $0.526-1$ \\
\hline
\end{tabular}

As mentioned in the methodology section, the classification of the obtained coefficients of the NDVI into vegetation types primarily depends on numerous factors such as: the latitude of the analyzed area, the altitude on which the vegetation extends etc. There are multiple approaches for classifying NDVI coefficients, but not a single one defines and outlines a strict limit of positive values. On the basis of processing of satellite images and validation in the field, the researcher determines limit values. However, common practice allows usage of scale of positive NDVI values proposed by the NASA (Earth Observatory of NASA).

To determine the density of green on a patch of land, researchers must observe the distinct colors (wavelengths) of visible and near-infrared sunlight reflected by the plants. As can be seen through a prism, many different wavelengths make up the spectrum of sunlight. When sunlight strikes objects, certain wavelengths of this spectrum are absorbed and other wavelengths are reflected. The pigment in plant leaves, chlorophyll, strongly absorbs visible light (from 0.4 to $0.7 \mu \mathrm{m}$ ) for use in photosynthesis. The cell structure of the leaves, on the other hand, strongly reflects near-infrared light (from 0.7 to $1.1 \mu \mathrm{m}$ ). The more leaves a plant has, the more these wavelengths of light are affected, respectively.

Therefore, very low values of NDVI ( 0.1 and below) correspond to barren areas of rock, sand, or snow. Moderate values represent shrub and grassland (0.2 to 0.3 ), while high values indicate temperate and tropical rainforests (0.6 to 0.8) (Hamel et al., 2009; Cui et al., 2013; Zaitunah et al., 2018). 
It can be observed that different types of forest vegetation (broad-leaved, coniferous, and mixed forest areas) prevail in all analysed municipalities (Fig. 4).

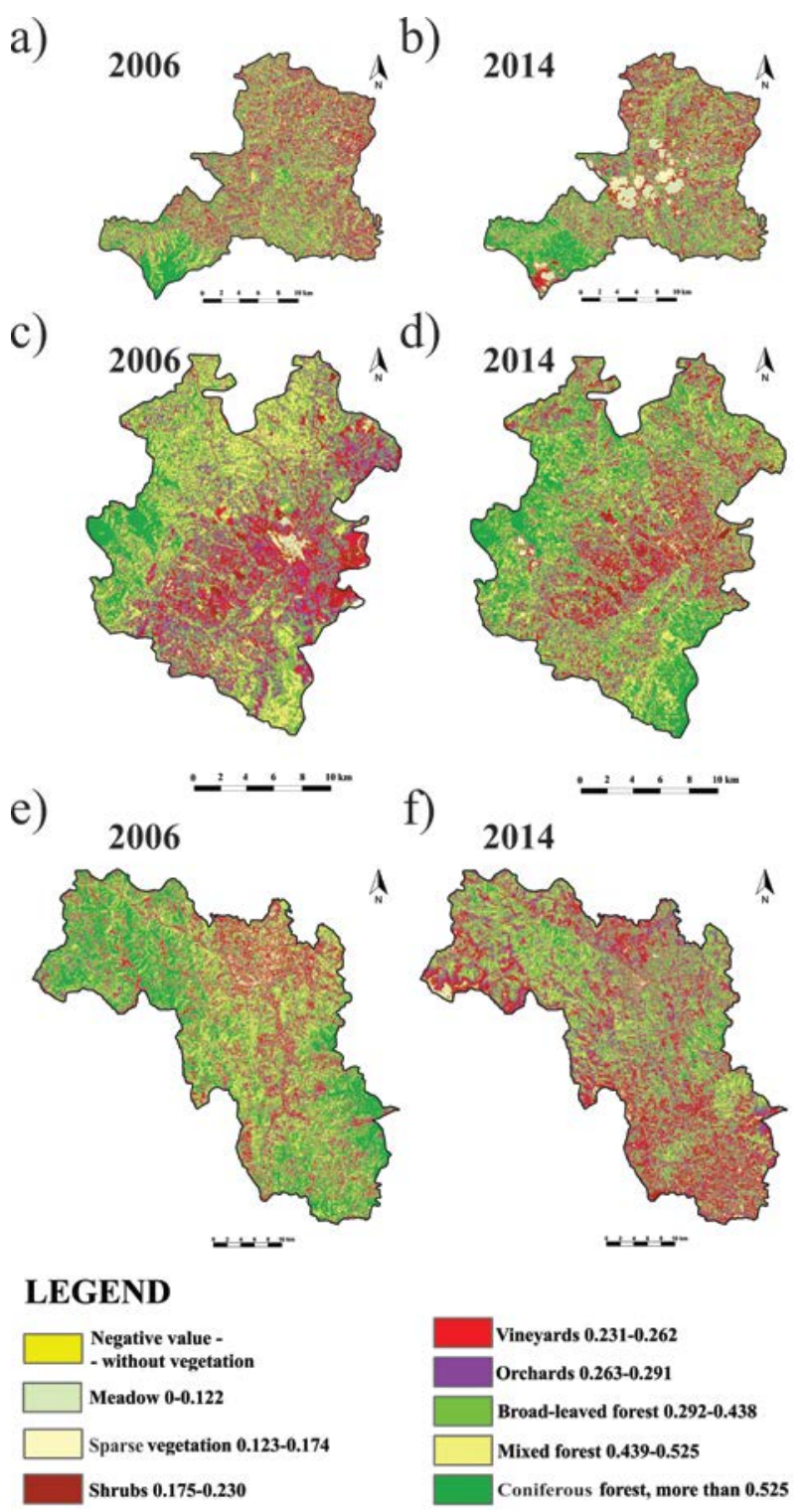

Figure 4. Vegetation type obtained by NDVI for Topola (a, b), Jagodina (c, d), and Kuršumlija (e, f) municipalities

Broad-leaved forest areas are the most pronounced vegetation type in all observed case studies. Jagodina Municipality is displaying a moderate increasment (from $48.18 \%$ in 2006 , up to $54.11 \%$ in 2014). On the other hand, Topola and Kuršumlija Municipalities, have slightly decreasing values ranging from $38.67 \%$ in 2006 , down to $37.12 \%$ in 2014 and $83.11 \%$ in 2006, down to $82.70 \%$ in 2014 (Fig. 5). This declining trend can be observed for both, coniferous and mixed forest areas and can be explained (especially for the Kuršumlija Municipality) by the presence of anthropogenic impact due to the continuously pronounced illegal logging activates (Jovanović et al., 2018).

New territories under meadow and sparse vegetation are spotted in the south-western and central part of Topola. Sparse vegetation areas have a relatively uniform distribution in Jagodina and Kuršumlija. Orchard areas are displaying an increasment in Topola and Kuršumlija Municipalities. Areas occupied by vineyards have a higher share of cover type in the Jagodina and Topola municipalities in contrast to Kuršumlija. This observation could be explained by the terrain hypsometry (Fig. 1). Other types of vegetation cover, such as shrubs display certain fluctuations: in Topola and Kuršumlija declining trend can be observed, while in Jagodina, this type of vegetation cover has doubled between two observed periods (Fig. 5). On the other hand, meadows have a more dominant presence in the Jagodina Municipality due to the specific physical features of the terrain.

Generally, the largest calculated vegetation cover area is observed in the Kuršumlija Municipality. The values vary from $73 \%\left(697 \mathrm{~km}^{2}\right)$ in 2006, declining to 63\% $\left(604 \mathrm{~km}^{2}\right)$ in 2014.

Forest-area covering follows the tendency of the vegetation-area results, with $63 \%$ in 2006 to $53 \%$ in 2014. The highest percentage of forest area in the Kuršumlija Municipality is covered by coniferous forests (96-98\%), while the rest of the forests are mixed (0.9-2\%) and broad-leaved forests (0.6-1.5\%). Jagodina Municipality is the municipality with the lowest vegetation cover observed, ranging from $32 \%\left(149 \mathrm{~km}^{2}\right)$ in 2006 to $28 \%\left(130 \mathrm{~km}^{2}\right)$ in 2014 . The vegetation area of the Topola Municipality has a pronounced decline, ranging from $36 \%\left(127 \mathrm{~km}^{2}\right)$ in 2006 to $32 \%\left(114 \mathrm{~km}^{2}\right)$ in 2014. Furthermore, the Jagodina Municipality was covered with $18 \%$ of forest vegetation in 2006, with coniferous types dominating (82\%). During the 20062014 period, the forest cover decreased by $2 \%$. The forest area in the Topola Municipality also decreased from $14.6 \%$ in 2006 to $12.5 \%$ in 2014 .

The average forest area in Serbia occupies approximately $30 \%$ of its territory (Jovanović et al., 2018). Kuršumlija municipality has more than the state's average (53\%). On the other hand, the Topola and Jagodina municipalities have less forest area than the state's average. A comparison of the official forest area estimates and the NDVI results obtained for 2006 and 2014 (Table 3), indicate minor differences for the Topola Municipality. Also, no remarkable discrepancies were noted between official statistics and NDVI results. On the other hand, NDVI results for the Jagodina and Kuršumlija municipalities display certain discrepancies when compared to the official forest-area estimates. Obtained NDVI values exhibit some interesting results, providing space for further analysis and investigation. 
a)

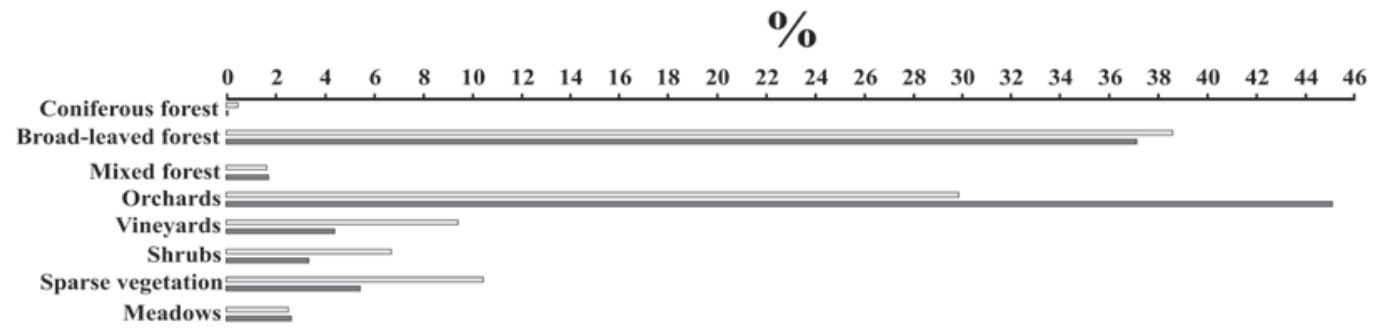

b)

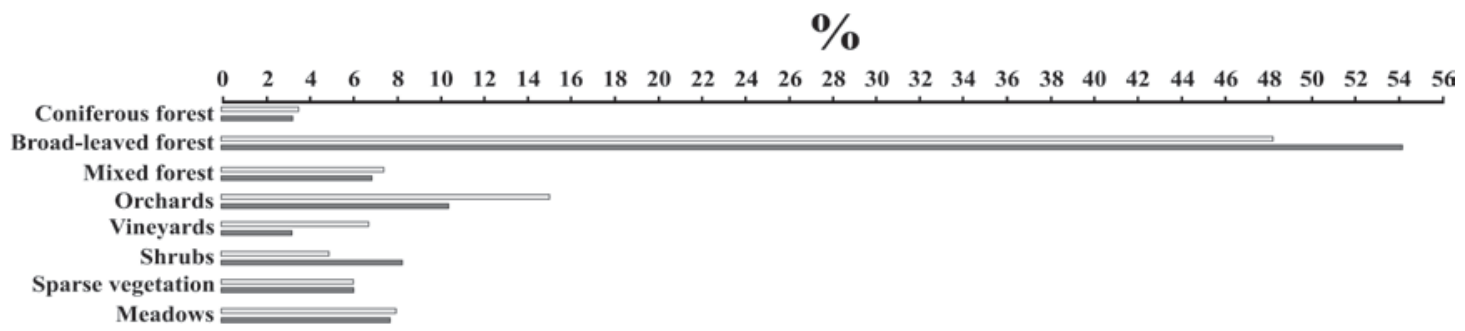

c)

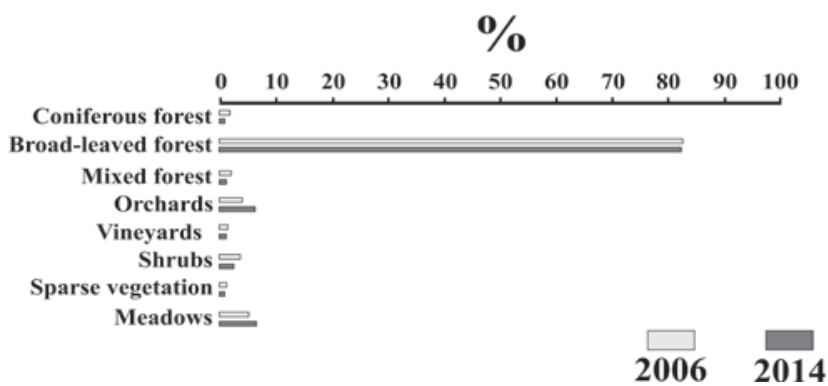

Figure 5. Classification of NDVI values into vegetation types for Topola (a), Jagodina (b), and Kuršumlija (c) municipalities

Table 3. Forest-area difference between the official statistical data and NDVI results for 2006 and 2014

\begin{tabular}{|c|c|c|c|c|c|}
\hline \multirow{2}{*}{ Municipality } & \multirow{2}{*}{$\begin{array}{l}\text { Municipality- total } \\
\text { area }\left[\mathrm{km}^{2}\right]\end{array}$} & \multirow{2}{*}{ Year } & \multicolumn{2}{|c|}{ Forest area $\left[\mathrm{km}^{2}\right]$} & \multirow{2}{*}{$\begin{array}{c}\text { NDVI - Official statistics } \\
\text { difference }\left[\mathrm{km}^{2}\right]\end{array}$} \\
\hline & & & $\begin{array}{c}\text { Official } \\
\text { statistics }\left[\mathrm{km}^{2}\right]^{\mathrm{a}}\end{array}$ & $\begin{array}{c}\text { Calculated on the } \\
\text { basis of NDVI }\left[\mathrm{km}^{2}\right]\end{array}$ & \\
\hline \multirow{2}{*}{ Topola } & \multirow{2}{*}{357} & 2006 & 52.00 & 52.12 & +0.12 \\
\hline & & 2014 & 47.51 & 44.34 & -3.17 \\
\hline \multirow{2}{*}{ Jagodina } & \multirow{2}{*}{470} & 2006 & 136.00 & 149.29 & +13.29 \\
\hline & & 2014 & 168.34 & 83.74 & -84.60 \\
\hline \multirow{2}{*}{ Kuršumlija } & \multirow{2}{*}{952} & 2006 & 604.41 & 577.4 & -27.01 \\
\hline & & 2014 & 546.47 & 507.85 & -38.62 \\
\hline
\end{tabular}

Source: Statistical Office of the Republic of Serbia

a at the end of 2006 and 2014

Since NDVI satellite images were obtained during the summer season, and official forest-area estimates were obtained at the end of the year, higher NDVI values than the official estimates were expected to some point. This prediction was expected especially for the Kuršumlija Municipality, taking into account the size of the municipality, forest cover (Table 3), and pronounced illegal logging activities. According to the state-owned forest management company "Srbija Šume", more than $40000 \mathrm{~m}^{3}$ of timber was illegally cut during the past 13 years in the Kuršumlija Municipality. This led to the loss of $10 \%$ of the forest area over the past few years (The
Republic of Serbia - Ministry of Agriculture, Forestry and Water Management - Directorate of Forests, 2006.; Anfodillo et al., 2008; Regional Environmental Center, 2009).

Data provided in Table 3 indicates large deviations between the results obtained through NDVI and official statistics. The reason for this is that official statistical data only relates to tall vegetation, while the NDVI results were obtained for all types of vegetation (meadows, pastures, bushes, etc.). This indicates that there is a wide range of possibilities for the inventory of vegetation by analysing satellite images. 
Until 2004 the stand inventories were conducted as an exclusive form of data collection for the growing stock in Serbia with inconsistent approach. First computer data processing and database standardization has been completed in 2006 by the National Forest Inventory.

The methodology is based on the EU countries experience (first of all Norway), and the guidelines and criteria of international organization dealing with forest ecosystem monitoring (UNFAO, UNECE, TBFRA, MCPFE, etc.) but with considering ecological and historically conditioned specificities of Serbian forest. The given concept includes systematic sample application in form of clusters ( $4 x 4 \mathrm{~km}$ grid with $4 \mathrm{~km}$ distance between reference points). Each cluster has 4 sample plots. The center of the first one is taken as intersection point of the cluster network, and the other three sample plots are distributed in the vertexes of the square the side of which is $200 \mathrm{~m}$. The sides of the clusters and squares with sample plots are oriented in north-south and east-west directions. The plot area is consisted of three concentric circles with the radiuses of $3 \mathrm{~m}, 10 \mathrm{~m}$ and $15 \mathrm{~m}$. The position of each tree is determined, i.e. the distance and azimuth to the plot centre, on the first plot within one cluster, which gives it the permanent character. The localization of the position in space of each cluster and sample plot is based on the maps with geographical and administrative-territorial division and the Code Manual for the National Forest Inventory of the Republic of Serbia: Topola Municipality in Šumadijski District, Jagodina Municipality in Pomoravski District and Kuršumlija Municipality in Toplički District (The national forest inventory of the republic of Serbia, 2009).

More noticeable differences between the official forest-area estimates and NDVI for the mentioned municipalities imply the need for using remote sensing techniques when performing complex analysis and data collection for the forestry sector. A great advantage of the NDVI method is that it could be performed very quickly and efficiently. In this way, NDVI can provide local forest managers with detailed and essential annual information regarding the forest inventory (Bellone et al., 2009; Fensholt et al., 2009; Martinez \& Gilabert, 2009; Alessandrini et al., 2010; Corral-Rivas et al., 2010; Jovanović \& Milanović, 2015; Milanović et al., 2016; Jovanović et al., 2018). This is also of crucial importance for preventing incorrect land use, negative anthropogenic impact, and the improvement of the methodology used for official statistical estimates.

\section{CONCLUSION}

The presented analysis for three topographically different municipalities in Central Serbia outlines the great possibilities of NDVI utilisation in monitoring and assessing temporal vegetation cover changes. The obtained results for Topola, Jagodina, and Kuršumlija municipalities indicate two major observations outlined for the investigated period of 2006-2014:

1) Vegetation cover in all case studies is experiencing a certain decrease, and this tendency is in line with the forest-area cover decrease, as confirmed by previous studies;

2) Certain discrepancies are observed between the NDVI and official forest-area statistics for the Jagodina and Kuršumlija municipalities. The obtained values (regarding the greater differences between datasets for 2006 and 2014) probably indicate the application of incorrect methodology in the forestry sector, incorrect land use, and the presence of a negative anthropogenic impact. Hence, it can be pointed out that NDVI is much more accurate than the conventional statistical approach.

It is evident that NDVI can provide local forest managers with essential, up-to-date information about vegetation cover changes on anannual basis, especially in southern Serbian municipalities with pronounced illegal logging (such as the Kuršumlija area). As shown in certain studies and outlined by the current study, NDVI is very promising for countries such as Serbia that seldomly perform national forest inventories. This approach is relatively cheap, efficient, easy to implement, and it also has a certain scientific objectivity regarding possible corruption in the sphere of forest management and the forestry sector in general. Also, as presented in the work of Kaim (2017), future investigation could include an analysis based on the usage of repeat photography which substantially could improve the knowledge of dynamical land change processes, including modifications or indications of change that are not visible on maps or on remote sensing images. We hope that the authorised institutions responsible for the vegetation inventory in the Republic of Serbia will use standard census methods in future, as well as remote detection methods (primarily NDVI). In this way, the state of the vegetation cover will be determined more accurately and accidental mistakes resulting from the current methods for vegetation monitoring will be reduced.

\section{Acknowledgement}

This research was supported by Project 176020 of the Serbian Ministry of Education, Science and Technological Development and by Project 114-451-2080/2017 of the Provincial Secretariat for Science and Technological Development, Vojvodina Province. Part of the research was supported by the HUSRB/1602/11/0057 - WATER@RISK - Improvement of drought and excess water monitoring for supporting water management and mitigation of risks related 
to extreme weather conditions.

\section{REFERENCES}

Alessandrini, A., Vessella, F., Di Filippo, A., Salis, A., Santi, L., Schirone, B. \& Piovesan, G., 2010. Combined dendroecological and normalized difference vegetation index analysis to detect regions of provenance in forest species. Scandinavian Journal of Forest Research, 25, 8, 121-125.

Anfodillo, T., Carrer, M., Giacoma, E., Lamedica, S. \& Pettenella, D., 2008. Challenges and priority for adapting the management of Carpathians forests to new environmental and socio-economic conditions. University of Padova: Padova, 152.

Bakx, P., 1995: Digital image processing of remotely sensed data. Enschede. 1-270

Basarin, B., Vandenberghe, D. A. G., Marković, S. B., Catto, N., Hambach U., Vasiliniuc, S., Derese, C., Rončević, S., Vasiljević D. A. \& Rajić, L., 2011. The Belotinac section (Southern Serbia) at the southernlimit of the European loess belt: preliminary results. Quaternary International, 240, 128-138.

Bellone, T., Boccardo, P. \& Perez, F., 2009. Investigation of vegetation dynamics using long-term normalized difference vegetation index time-series. American Journal of Environmental Sciences, 5, 460-466.

Brack, D., 2003. Illegal logging and illegal trade in forest and timber products. International Forestry Review, 5, 3, 196.

Blaster, J., Contreras, A., Oksanen, T., Puustjärvi, E. \& Schmithüsen, F., 2005. Forest law enforcement and governance process for Europe and northern Asia. World bank, Washington DC.

Chavez, S. jr. 1996. Image-Based Atmospheric Corrections Revisited and Improved. Photogrammetric Engineering and Remote Sensing, 62, 9, 1025-1036.

Cui, X., Gibbes, C., Southworth, J. \& Waylen, P., 2013. Using Remote Sensing to Quantify Vegetation Change and Ecological Resilience in a Semi-Arid System. Land, 2, 108-130.

Corral-Rivas, J.J., Wehenkel, C., Castellanos-Bocaz, H.A., Vargas-Larreta, B. \& Dieguez-Aranda, U., 2010. A permutation test of spatial randomness: application to nearest neighbour indices in forest stands. Journal of Forest Research, 15, 218-225.

Edmunds, D. \& Wollenberg, E., 2004. Local forest management -the impacts of devolution policies. Earthscan, London.

Finelli, M., Gelli, G. \& Poggi, G., 1996: Multispectral-image coding by spectral classification. Proceedings: International conference on image processing 2 . Lausanne.

Fensholt, R., Rasmussen, K., Nielsen, T.T. \& Mbow, C., 2009. Evaluation of earth observation based long term vegetation trends - Intercomparing NDVI time series trend analysis consistency of Sahel from AVHRR GIMMS, Terra MODIS and SPOT VGT data. Remote Sensing of Environment, 113, 1886-1898.

Franklin, S. E., 2001. Remote sensing for sustainable forest management. Lewis Publishers, London. 407.

Grădinaru, S.R., Kienast, F. \& Psomas, A., 2017. Using multi-seasonal Landsat imagery for rapid identification of abandoned land in areas affected by urban sprawl. Ecological Indicators, 57, 305-313

Griffiths, H.I., Kryštufek, B. \& Reed, J.M. (Eds.), 2004. Balkan Biodiversity - Pattern and Process in the European Hotspot. Springer, 343.

Hamel, S., Garel, M., Festa-Bianchet, M., Gillard, JM., D. \& Cote, S. D., 2009. Spring Normalized Differences Vegetation Index (NDVI) predicts annual variation in timing of peak faecal crude protein in mountain ungulates. Journal of Applied Ecology, 46, 582-589.

Jensen, J. R., 2007. Remote Sensing of the Environment: An Earth Resource Perspective. Upper Saddle River, NJ, Prentice-Hall.

Johnson, L. F. \& Trout, T. J., 2012. Satellite NDVI Assisted Monitoring of Vegetable Crop Evapotranspiration in California's San Joaquin Valley. Remote Sensing, 4, 2, 439-455.

Jovanović, D., Govedarica, M., Sabo, F., Bugarinović, Ž., Novović, O., Beker, T. \& Lauter, M., 2015. Land Cover change detection by using Remote Sensing - A Case Study of Zlatibor (Serbia). Geographica Pannonica 19, 162-173.

Jovanović, M. M. \& Milanović, M. M., 2015. Normalized Difference Vegetation Index (NDVI) as the basis for local forest management. Example of the municipality of Topola, Serbia. Polish Journal of Environmental Studies, 24, 2, 529-535.

Jovanović, M. M., Milanović, M. M. \& Zorn, M., 2018. The use of NDVI and Corine Land Cover databases for forest management in Serbia. Acta Geographica Slovenica, 58, 1, 109-123.

Kaim, D., 2017. Land cover changes in the polish carpathians based on repeat photography. Carpathian Journal of Earth and Environmental Sciences, 12, 2: $485-498$.

Ladányi, Z., Rakonczai, J. \& Leeuwen, B., 2011. Evaluation of precipitation-vegetation interaction on a climate-sensitive landscape using vegetation indices. Journal of Applied Remote Sensing, 5, 053519.

Marković, S. B., Korać, M., Mrđić, N., Buylaert, J. P., Thiel, C., McLaren, S. J., Stevens, T., Tomić, N., Petić, N., Jovanović, M., Vasiljević, Đ. A., Sümegi, P., Gavrilov, M. B. \& Obreht, I., 2014. Palaeoenvironment and geoconservation of mammoths from the Nosak loess-palaeosol sequence (Drmno, northeastern Serbia): Initial results and perspectives. Quaternary International 334-335, 3039.

Markus-Johansson, M., Mesquita, B., Nemeth, A., Dimovski, M., Monnier, C. \& Kiss-Parciu, P., 2010. Illegal logging in South-eastern Europe. Wold bank, Washington DC. 73-101, 124-127.

Martinez, B. \& Gilabert, M. A., 2009. Vegetation dynamics from NDVI time series analysis using the wavelet transform. Remote Sensing of Environment, 113, 1823-1842. 
Meng, Q., Cieszewski, C. \& Madden, M., 2009. Large area forest inventory using Landsat ETM+: A geostatistical approach. ISPRS Journal of Photogrammetry and Remote Sensing, 64, 27-36.

Milanović, M. M., Perović, V. S., Tomić, M. D., Lukić, T., Nenadović, S. S., Radovanović, M. M., Ninković, M. M., Samardžić, I. \& Miljković, Đ., 2016. Analysis of the state of vegetation in the municipality of Jagodina (Serbia) through remote sensing and suggestions for protection. Geographica Pannonica, 20, 2,70-78.

Milanović, M., Tomić, M., Perović, V., Radovanović, M., Mukherjee, S., Jakšić, D., Petrović, M. \& Radovanović, A, 2017. Land degradation analysis of mine-impacted zone of Kolubara in Serbia. Environmental Earth Sciences, 76, 580.

Obreht, I., Buggle, B., Catto, N., Marković, S. B., Bösel, S., Vandenberghe, D. A. G., Hambach, U., Svirčev, Z., Lehmkuhl, F., Basarin, B., Gavrilov, M. B. \& Jović, G., 2014. The Late Pleistocene Belotinac section (southern Serbia) at the southern limit of the European loess belt: Environmental and climate reconstruction using grain size and stable $C$ and $N$ isotopes. Quaternary International, 334-335, 10-19.

Rašković, D., 2015. Anthropogenic impacts on the stability of the forest ecosystems in Belgrade - comparative analysis of Košutnjak Forest and Zvezdarska Forest. Bulletin of the Serbian Geographical Society, 4, 195214.

Regional Environmental Center (REC), 2009. Illegal logging activities in the Republic of Serbia - A FACTFINDING STUDY. Regional Environmental Center: Belgrade, 47.

Shmitt, U. \& Ruppert, G., 1996.Forest classification of multispectral mosaicking satellite images. Archives of Photogrammetry and Remote Sensing 31.

Statistical Office of the Republic of Serbia (SORS), 2011. Municipalities and regions of the Republic of Serbia, 2011. Statistical Office of the Republic of Serbia, Belgrade.

Statistical Office of the Republic of Serbia (SORS), 2014. Municipalities and regions of the Republic of Serbia, 2014. Statistical Office of the Republic of Serbia, Belgrade.

The Republic of Serbia - Ministry of Agriculture, Forestry and Water Management - Directorate of Forests 2006. Forestry Development Strategy for Serbia. Belgrade.

The Republic of Serbia - Ministry of Agriculture, Forestry and Water Management - Directorate of Forests 2009. THE NATIONAL FOREST INVENTORY OF THE REPUBLIC OF SERBIA: The growing stock of the Republic of Serbia. Belgrade.

Tzedakis, P. C., Lawson, I. T., Frogley, M. R., Hewitt, G. M. \& Preece, R. C., 2002. Buffered Tree Population Changes in a Quaternary Refugium: Evolutionary Implications. Science, 297, 2044-2047.

Wang, Q. \& Tenhunen, J., 2004. Vegetation mapping with multitemporal NDVI in North Eastern China Transect (NECT). International Journal of Applied Earth Observation and Geoinformation, 6, 17-31.

Willis, K.J., 1994. The vegetation history of the Balkans.Quaternary Science Reviews, 13, 769.

Zaitunah, A. Samsuri, Ahmad, A. G. \& Safitri, R. F. 2018. Normalized difference vegetation index (ndvi) analysis for land cover types using landsat 8 oli in besitang watershed, Indonesia. IOP Conference Series: Earth and Environmental Sciences, 126, 012112. 